\title{
Ability within disability: Reflective memories shared with Dr Kasturi Varley
}

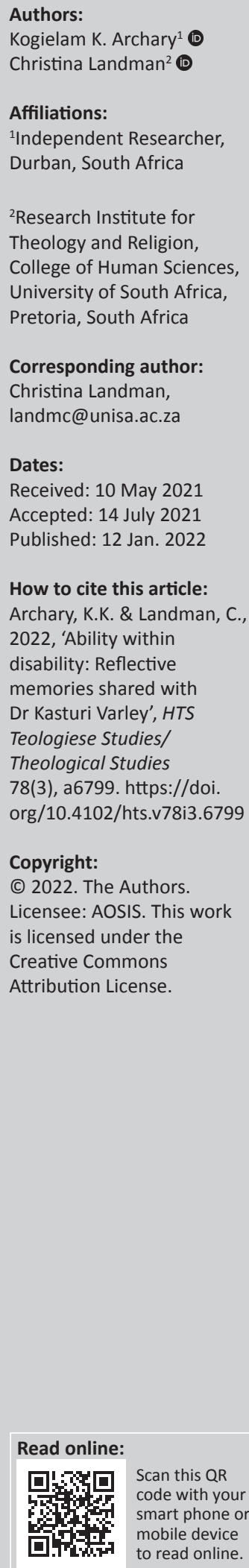

In a post-apartheid South Africa, the value of reflective memories and their impact on community history gives credibility to their relationship with personal struggles such as disability, be it physical or political. Shaped by South African Indian heritage, an isolated individualised case of a second-generation descendant's ability-disability experience is researched and narrated in this article. The respondent, Dr Kasturi Varley is a woman of the South African Indian community, who was born almost 101 years after the first shipload of Indian indentured labourers arrived in the then Colony of Natal. Her memories shed light on a unique Indo-African-European experience. Her indentured paternal grandfather arrived in the African continent in August 1900. Her reflective memories and shared experiences of various episodes of the ability-disability paradigm add to the body of knowledge of the Indian indentured labour system that already exists and partially fills up the prevalent gaps in the research on this topic. Her story is unique in that she worked wheelchair-bound at the International Atomic Energy Agency in Vienna, Austria and subsequently settled in the United Kingdom. This study applied a qualitative research methodology.

Contribution: This article provides insight on reflective memories within the domain of social memory and contributes to an understanding of the historiography of the descendants of Indian indentured labourers in South Africa. In 2020, this community commemorated the 160th anniversary of the arrival of the labourers to the Colony of Natal.

Keywords: colonisation; indenture; South African Indian community; disability; reflective memories; social memory; post-apartheid South Africa; Dr Kasturi Varley; enablement.

\section{Introduction}

\section{Aim}

This article chronicles the story of Dr Kasturi Kalyanee Varley (nee Pillay) who was born on the 1st of August 1959 and is the granddaughter of Rungasamy Pillay and the daughter of Pakkiry Pillay. The aim of this article is to highlight the ability within disability of Dr Varley by narrating her story. Her disability includes both physical and political disabilities.

\section{Reason for the study}

The broader reason for undertaking this study is to focus on the 160th anniversary (18602020) of the arrival of the Indian indentured labourers to the Colony of Natal. The primary reason for this research is to study the ability-disability paradigm as it pertains to the Indian female descendants of the colonised labour force who were transported from India onto the African soil.

\section{Literary review and own contribution}

During the years from 1860 to 1911, a total of 152184 Indian nationals arrived in the Colony of Natal. They were transported to this country to work mainly on the sugar plantations. They were known as the Indentured Indians who were supposed to return to India after their contracts have expired. In order to maintain the labour, in 1885 , a $3 £$ tax was implemented on formerly indentured Indians who failed to return to India after completing their contracts. By 1910, nearly $26.85 \%$ of indentured men returned to India. However, most chose to stay and thus constituted the forebears

Note: Special Collection: The World in Troubled Times: Oral History Challenges and Opportunities, sub-edited by Christina Landman (University of South Africa) and Sekgothe Mokgoatšana (University of Limpopo). 
of the majority of present-day South African Indians. There is available literature on Indian indenture. Bhana (1991), Desai and Vahed (2010), Meer (1969), Mishra (2008), and Tinker (1974) have written extensively on different aspects of indenture. However, the literature review revealed that there is a severe lack of information, documentation and academic research on the theme of ability within disability and the female descendants of indentured labourers. Because there are no academic works on this aspect available, this article - as South African Indians reflect on their heritage of 160 years in the country of their birth attempts to answer some of the questions regarding the information on the topic of ability within disability and the female descendants of the South African Indians by reflecting on the story of Dr Varley.

\section{Methodology}

The respondent consented to a telephonic interview. On 12 January 2021, a short telephonic interview coupled with a longer and more comprehensive written communication with responses from the respondent were utilised. The case study methodology was used as case studies provide opportunities for greater depth investigations of a single person, group, event or community (Johansson 2007). Typically, data are gathered from a variety of sources and by using several different methods (e.g. interviews), but the research population for this article is restricted to Dr Varley, a quadriplegic. The term case study is also often taken to carry implications for the kind of data that are collected, and perhaps also for how these are analysed. Frequently, but not always, it implies the collection of unstructured data, and the qualitative analysis of those data (Gomm, Hammersley \& Foster 2000:3) The aim of case study research is to capture them in their uniqueness rather than to use them as a basis for wider generalisations. During the interview and written correspondences, the respondent brought alive the past by sharing experiences of the various roles that she has played in life. The respondent began penning the aspects of her story for a newsletter when she worked in Vienna. The original intention of writing about her life, according to Dr Varley, was:

$[T]$ o enlighten friends, family, colleagues, general persons and visitors to the Vienna International Centre that they may encounter a crazy woman whizzing past in a wheelchair. It's hard to believe but sometimes I ask myself why do people walk so slowly - forgetting that I used to be a walking person too! (ECHO 2010:n.p.)

ECHO is an International Atomic Energy Agency (IAEA) Staff Journal/newsletter that is published by the IAEA. For the purposes of this article, a semi-structured questionnaire was utilised. A semi-structured questionnaire allows the respondent the freedom to identify and isolate what details are significant for them at that point in time, in terms of their recollection of the past. Semi-structured interviews consist of several key questions that help to define the areas to be explored, but also allows the interviewer or interviewee to diverge in order to pursue an idea or response in more detail (Britten 1999:11-19). This interview format is used most frequently when researching individualised cases (biographies, ethnographic autobiographies, etc.), as it provides the participant with some guidance on what to talk about, which they may find helpful. At the same time, the flexibility of this approach, particularly compared to structured interviews, also allows for the discovery or elaboration of information that is important to participants but may not have previously been thought of as pertinent by the interviewer.

The interview was not tape-recorded as the respondent was satisfied with answering questions and the interviewing author (K.K.A.) writing them down. At the time of the interview, the author was (and still is) based in Durban and the respondent was retired and living in the United Kingdom. During the interview through longer telephonic discussions, issues related to the connectivity and data usage were encountered as limitations. Therefore, the respondent and the interviewing author mutually agreed to the preferred use of email communication.

\section{Thematic concepts}

The following concepts are referred to in the article as the themes revolve around them. The interviewing author provides her understanding of these concepts as they apply to the article.

\section{'Colonialism'}

The British colonised India, South Africa and many other countries around the world. During colonisation, mass movement of people took place across the continents. As people were transported over the oceans, they took with them their ancestral heritage. They also became acculturised to their new places of living. The later generation displaced Indian community, having gone through the globalised political systems of colonisation and indenture, still face further political disenfranchisement, pre- and post-1994.

\section{'Indenture'}

Indentured labour was not free labour. The workers who, either voluntarily or involuntarily went to distant places had no right to a negotiated wage or to the choice of employment and the category of work. The structures created by the Government of India in collaboration with the legislatures of the labour-receiving colonies imposed severe restrictions. The regulated movement of indentured workers from the Indian sub-continent to the Colony of Natal was abolished in 1911 after the Indian government legislated this into an Act.

\section{'South African Indian community'}

The term South African Indian refers to South African citizens whose ancestry dates back to the period of colonisation and Indian indenture. This community is made 
up of descendants of the Indian migrants who were either indentured to the Colony or came as free passengers or merchants. They proudly see themselves as South Africans, born on the African soil, but at the same time, those who follow Indian traditional customs, celebrate certain Indian religious festivals and dress accordingly during events such as weddings and other ceremonial gatherings. The Indian community is a blended, multi-cultural community as elements of other cultures are prevalent with the parameters of the South African Indian life.

\section{'Ability-disability paradigm'}

A disability is any condition of the body or mind of a person that makes it difficult for him to do certain activities and interact with the world around him. For the purposes of this article, topics related to personal physical disability and 'political disability' are considered. Personal physical disability is a condition which adversely affects the functions of limbs or any other body parts of a person which result in various types of disabilities, such as the loss of mobility. 'Political disability', in this case refers to the processes of colonisation and indenture which created a sense and reality of political uncertainty within members of the affected communities that experienced these aspects of political upheaval.

\section{Interpretation of results}

In terms of the interpretation of the results, a noninterpretative, thematic approach has been used in this research (Stern et al. 1998). The respondent provided her reflections on her own life, and the authors recorded them in this article unmediated, that is, not analysing, mediating or interpreting them. These unmediated reflections are, however, organised under themes captured as follows: The Colonial Era, Indenture, South African Indian Community and the ability-disability paradigm. These themes have been further explored under sub-themes.

\section{Structure of the article}

The article follows a simple structure. An introduction provides the aim of the research and the methodology used to reach that aim. A second shorter part will give the background to the history, or rather herstory, of Dr Varley. The main body of the article contains the unmediated reflections of the respondent, which are arranged thematically. These themes were identified from the interview in terms of the respondent's reflective memories. What follows is an introduction which includes the background to Dr Varley's story. The article closes with a conclusion containing a summary of the research results.

\section{Background to the story of Dr Kasturi Varley}

Dr Kasturi Varley is a second-generation South African of Indian descent. She was an able-bodied person who became a quadriplegic. Her physical disability was challenging. However, her unique abilities allowed her to enable herself.

\section{A life of struggle for achievement during the colonial era in Natal}

The term struggle has a wide connotation but can be defined as making a very great effort in order to achieve something, in spite of experiencing various difficulties in life. During the period of colonialism, the indentured labourers knew, as they travelled, that they would face a life of struggle in Africa, but they also knew that they could overcome those difficulties as they had heard the tales of achievement from the earlier returning cohorts. It was not any different for the Pillay patriarch and it was a life of struggle for achievement where his abilities were utilised to transfer from an indentured status to a free or passenger status. When Rungasamy Packree Pillay, the 19-year-old Indian indentured labourer, with the register number 80619 , left the district of Tanjore, in the Thanna of Kumbaconum which is situated in the Village of Ammanpettai in the state of Tamil Nadu, for the Colony of Natal, it can only be assumed that he valued his many abilities. As he travelled the high seas and crossed continents, from the departure Port of Madras to the arrival Port of Natal in Durban on board the Umkuzi IV, he must have thought about how he would be enabled in his homeland. His tenure in the new country bodes well as, at the time of his death on 23rd April 1947, he was viewed as being successful. He chose to remain in Natal as his status transferred from being indentured to a free citizen. Being a talented musician, he was able to continue with his hobby of karnatic singing (South Indian style of singing). He ensured that his children achieved some level of education. The basis of this enablement was developed on cultural, traditional, and educational propensities. His granddaughter graduated from the recognised universities in the United Kingdom and South Africa, thus aligning the vision of her grandfather to a later generation. He was a successful person who possessed the ability to change the circumstantial conditions of his life and this perception has been conceptualised in the Pillay family as seen in the narrated reflective memories of Dr Varley. Rungasamy Pillay came to the Colony of Natal in 1900. His eldest son, Pakkiry Pillay was Dr Varley's father. Despite being of indentured heritage, Pakkiry Pillay displayed great ability and was the founder and managing director of Pakco, a food manufacturing company (non-perishables; packaged, canned and bottled products) based in Verulam. Dr Varley was (and still is) a woman of great ability and was able to achieve whatever she set out to do. But, just like any other woman in the world, she was also subjected to prejudice and has experienced many difficulties in life, even though it had nothing to do with her ability. Women, in most societies throughout the world, over time, have been involved in various struggle issues. South African Indian women like Dr Varley were not new to this phenomenon of struggle. The core value system of the South African Indian is based on formal education. Being educated in terms of qualifications that reflect certificates, diplomas, degrees and post-graduate achievements is not only expected but also well received in this community. In 2000, the highly educated and abled Dr Varley was involved in an accident which left her disabled. Despite this disability, she went on to become a leader at the Vienna International Centre (VIC). 


\section{An enabling opportunity in life}

From the accounts of Pillay family folklore and tales passed down over the generations, the interviewing author has been able to glean information about their personal struggle and later life achievements. Those achievements in their life, being demonstrated from their ancestors to future generations was a part of their psychological tapestry. For Rungasamy Pillay, it was a new life when he boarded the ship. After the loss of his first wife, his eldest son advised him to remarry. So, he returned to India, and came back with his new bride who now inherited five children. Thereafter, the couple had four children. Rungasamy Pillay ensured that the family overcame their current difficulties and this ability to overcome became an enabling baton that was passed down through the generations. The entrepreneurial ability amongst his sons witnessed the birth of an internationally recognised family business Pakco. Through the abilities of Pakkiry Pillay, his immediate family were able to live a comfortable life; his second wife, Nagamall Pillay, resigned from her teaching post, and his son Professor Ugaraja Pillay and daughter Dr Kasturi Varley both lived and studied in various parts of the world during Apartheid, having returned when their father became unwell.

\section{Reflective memories: Newsletter, emailed correspondence and interview}

In terms of the theoretical framing of this research, it is imperative to comment on reflective memory. Reflective memory supports and enables social interactions in a variety of ways. Social interaction constitutes one aspect of social memory. Aspects of reflection or reflective memory have reference to individual working memory. This is important within social memory as it is these thoughts that are activated and consequently inform the present. Reflective memory constitutes the selection, maintenance, and manipulation of the content of working memory. Hence, the importance of reflective memory within social memory is featured in this article.

The following content comprises part of a short telephonic interview (12 January 2021) as well as longer written responses from the respondent. The respondent was satisfied with the emailed responses being used for this article. Information was also obtained from a Newsletter article (ECHO 2010) written by the respondent when she worked in Vienna. The information has been arranged under themes as identified earlier and subheadings which provide information emanating from the interview as well as from emailed responses.

\section{'Political disability'}

Economically speaking, her situation was no different to women throughout the world as she stated, 'I worked for a charity organisation called Operation Hunger for 7 months. I found it difficult to get employment despite holding a $\mathrm{PhD}^{\prime}$ (Interview, 12 January 2021). This research endeavour of looking at what South African Indian women have experienced is what is fascinating to research and report on as each singular contribution adds to the tapestry of life in
South Africa. A story which is having elements of postapartheid, international schooling, marriage, childbirth, divorce, being disabled, a second marriage and surviving day by day, is what that justified this research as it touched the base with the value and significance of oral history. Personal memories reflected in the chronology of life events of Dr Varley indicated 'political disability' as a young adult. She says:

'I grew up during the apartheid era with all the unjust rules and traditions imposed on girls by the Indian community and the government ruling party. Daddy was a typical Indian man in many respects but being the apple of his eye, he adored me to no end, giving me all the opportunities that were usually only granted to Indian boys.' (email, 12 June 2020)

Her ability within the disability that she currently bears highlights her survival identity which perhaps stems from the opportunities that her father gave her as a youngster. In terms of recommendations for further study, the issue of other aspects of the ability-disability paradigm can be researched. Despite being descendants of Indian labourers, South African Indians have come a long way in terms of their settlement in Africa. Whilst this article acknowledges the suffering caused by colonisation, indenture and apartheid as political systems in place, it does not offer a panacea to solve the resultant problems related to the personal or 'political disability' inflicted on later generations.

Enabling himself, Rungasamy Pillay (1881-1947) left his family in Chennai, India, boarded a ship headed for Natal and landed with just clothes on his back and a handful of necessities. He married in 1903 and his wife gave birth to five children, the eldest son being Pakkiry Pillay (19041993). Dr Varley grew up and lived in both Tongaat and Verulam which were historically small Indian settlements situated in Natal. During colonisation, Natal was known as the Colony of Natal. During post-apartheid period, it is called the Province of KwaZulu Natal. Indian, coloured and black townships were legislated establishments. These oppressive laws forced the man on the street to fight the system. The liberation struggle was a multi-racial battle where comrades worked together to bring down the regime. Pakkiry Pillay is known to have provided financial and other ways of support to the apartheid victims as Dr Varley mentioned:

'Dad used to send his canned Pakco products to Mandela when he was on Robben Island. My maternal uncle and family had a remarkably close relationship with Winnie and Nelson Mandela.' (Interview, 12 January 2021)

By 1974, Pakkiry Pillay identified the intellectual ability of his daughter, 'I was very fortunate that my dad was able to send me to the United Kingdom to complete my education. I left South Africa at the age of $14^{\prime}$ (Interview, 12 January 2021). She studied at the Farringtons Girls School based in Chislehurst, Kent. She completed the ' $\mathrm{O}$ ' and 'A' levels. In 1980, she graduated with a BSc (Hons) degree at the 
University of London, studied for a Post Graduate Certificate in Education and taught in the United Kingdom for 2 years.

Because of her father's ill health, she returned to Verulam in July 1985 which enabled her to spend time with her father. She and Kuldip Jutle, of Sikh ancestry whose family moved from India to London when he was 12, were married in March 1986 in a traditional Hindu wedding in Durban. Their only daughter, Rashika Kaur Jutle was born on 09 February 1988. She completed a Master of Science (1987) and Doctor of Philosophy in Chemistry (1991) at Natal University.

After the 1990 new dispensation that was being negotiated by the stakeholders, previously disadvantaged South Africans expected change. However, to a certain extent, this created further 'political disability' as indicated by Dr Varley:

'In spite of holding a doctorate degree in Chemistry I was unable to find employment with that qualification. This was due to the oppressive apartheid system that was prevalent at the time. I then found a job as a laboratory assistant at the South African Nuclear Fuel Co-operation (NUFCOR).' (ECHO 2010:n.p.)

Because of her academic and vocational abilities, she worked there for five years and was then employed by the National Nuclear Regulator (NNR) where:

$[O]$ ne of my responsibilities was to regulate the transport of radioactive material for industrial use throughout South Africa. As a result of this occupation, I was the South African representative to the International Atomic Energy Agency Transport Standards Safety Committee (TRANSSC) which had members from all over the world. (ECHO 2010:n.p.)

\section{Personal disability}

Disability became a new life status for Dr Varley. In terms of a brief history of her present condition, she shared that on her 41st birthday, she was driving home from her job as a manager at the NNR when she had a burst tyre and lost control of the car. Luckily for her, a driver on the other side of the dual carriage way observed her car overturning. The driver came to her assistance and finding her mobile phone in her briefcase he called the first number he found, which luckily was that of Allan, her partner of 6 years. Dr Varley said that 'Allan and my daughter Rashika, then 12 years old, went out to the scene of the accident and I was transferred by helicopter to Sunninghill Hospital in Johannesburg' (email, 12 June 2020). About a year after the accident she asked Rashika about her feelings and thoughts when she had arrived at the scene of the accident. Rashika responded:

'I was 12 years old sitting in the front seat of an ambulance while paramedics bustled in the middle of the freeway trying to help my mother. A nice lady paramedic sat with me; we did not talk much. I was not scared. I knew what had happened and I also knew that it was serious. As I watched red and blue lights flash and a helicopter landed I felt an odd sense of obligation to ask, as I had seen so many times in the movies, "Is my mother going to die?" The lady replied that three of the best doctors were helping her. I chuckled to myself and thought, "And when we need the fourth one she decides to be a patient."' (email, 12 June 2020)

Mother and daughter had a good giggle then.

\section{An accident: Not death but a change in life as disability set in}

Dr Varley had no recollection of the months that followed. Her dear friends, Sharon, Anita and Ruma visited her in the hospital when they heard about the accident. They were college friends from the University of London. Dr Varley said that she has a:

' $[L]$ ife-long relationship with each of them. Sadly, I was in no state to know that they were by my side. Being heavily sedated after the accident I only vaguely remember being conscious at the end of October or the beginning of November 2000. My then manager at the Reactors Assessment Department (RAD) for the nuclear power station and dear friend, Dick Kirk, on the pretence of being a family member, visited me as often as he could. In discussions with physicians and nursing staff he enquired about my condition, progress and prognosis for the future.' (ECHO 2010:n.p.)

For the first 3-4 months, the picture was bleak, being a life and death situation or at the best survival as a quadriplegic. Being his meticulous self, Dick Kirk sent regular updates on her status to friends, colleagues, including the IAEA (https: / / www.iaea.org), the Transport Safety Unit (TSU), and members of TRANSSC and her family all over the world. In fact, this report of what happened up until she returned to work is based on Dick Kirk's e-mail communication on Dr Varley's progress:

My treatment was not at all straightforward. Brain scans and X-rays to assess the extent of injuries to my brain and nervous system were delayed as I was on a respirator due to congestion of my lungs. Water had to be drained from my brain. (ECHO 2010:n.p.)

Later she had a tracheotomy. There were many other complications such as septicaemia (apparently brought about by the trauma of accident), lung infections, pneumonia, and the presence of methicillin resistant staphylococcus aureus (MRSA):

I was placed in isolation with only family members allowed to visit. My spine was immobilised at fracture points. I had no response to outside stimulus. I spent eight months in hospital, six of which was in intensive care. I was discharged from hospital in April 2001. (ECHO 2010:n.p.)

She went home in a wheelchair which she could hardly push as her muscles had withered to nothing during the previous months. After being discharged, she had many subsequent stays in hospital. One such stay was to have Mitrofanoff surgery. In 2002, she decided to have this operation. Mentally, it provided her with the confidence of looking more of a 'normal' person, that is, not having a urine bag strapped to the side of the leg for the rest of her life:

'With no sensation I have to empty my bladder every two hours; day and night to stay dry. In reality, this does not always work. I have learnt that wetting myself also tells me that I have an infection, or something is not quite right. Other stays in hospital were related to having operations to stabilise my badly damaged right ankle.' (ECHO 2010:n.p.) 
In terms of her life struggle and subsequent achievements, how did she climb out of the situation she found herself in?

'I am an optimist, determined and fun-loving odd character and desperately wanted to get back to some normality obviously in an unimaginably different manner. I returned to work on 1st August 2001, exactly one year after that life changing day. I somehow tried to convince myself that I had not changed. Dick probably has other thoughts on this topic. He has seen me develop to try being a professional adult again.' (ECHO 2010:n.p.)

With the support and encouragement of her family, friends and with the help of the Almighty, Dr Varley had to learn to give herself strength. She was very depressed, frustrated and suicidal in the months and years to follow:

'I asked God: "I was so near death - why didn't you take me?" One thought that encouraged and spurred me on was the love and guidance given to me by my parents.' (Interview, 12 January 2021)

Whom she describes as two very special and important people in her life. 'My father's words of "God gave me a daughter at 55 - my darling you can do and be whatever you want in life" always rang in her head' (Interview, 12 January 2021). Remembering these words gave her the courage and determination to move ahead regardless of the situation that she was faced with. Her ability within the disabilities that she faced was able to overshadow the darkness of the many things that she could no longer do for herself. Her ability to still be positive and allowing herself to continue working is an indication of her inner strength. This was the same enabling inner strength that was displayed by her father, when he founded an international company and by her grandfather, when he set sail for a different life.

\section{7th July 2006 - Starting work at the International Atomic Energy Agency}

Dr Varley had held various positions at the NNR, initially as radiation and transport specialist. Thereafter, she worked in radiation protection and emergency planning and became the deputy manager in RAD and finally the manager of the Regulatory Research and Development (RRD). However, it has been her:

' $[D]$ ream to work at the IAEA ever since my first visit there in June 1996, as the South African representative at the TRANSSC meeting. As fate would have it, I met a staff - member, Gerrie Dicke of the TSU at a transport meeting in Ottawa in 1999 and asked when he was planning to retire, as I would very much like to apply for his position! The position was advertised in 2005. I applied on-line and was interviewed over the telephone. I was notified of my success in March 2006 and I agreed to assume duties as a Transport Specialist in NSRW [The Division of Radiation, Transport and Waste Safety] on 17th July 2006. While I was still in South Africa, dear friends, Ann and Rob Heard, offered their assistance.' (ECHO 2010:n.p.)
Following lots of e-mail correspondence between:

'Ann, myself and the owner, an apartment in a high - rise apartment block, directly opposite the Kaisermuehlen U-Bahn station was obtained prior to our arrival in Vienna. This apartment was so convenient and easily accessible by wheelchair to the VIC but in reality, the situation was somewhat different - what a shock to the system! On 17th July 2006, Allan and I gave ourselves an hour for me to report to duty.' (ECHO 2010:n.p.)

The VIC was designed by the Austrian architect Johann Staber and inaugurated on 23 August 1979. Located on the banks of the River Danube, it is only a 10 -min ride by underground (U-Bahn) to Vienna's city centre. (https:// www.iaea.org/events/guide-to-the-vic). Getting to the entrance to Wagramerstrasse was easy enough from the apartment. However, getting to Gate 1 became an impossible reality. There was just no way of getting to Gate 1 in the wheelchair. The only solution was taking the stairs leading to the entrance:

'Having no choice Allan had to lug some $90 \mathrm{kgs}$ up those stairs. Thank God as always, he was able to and I reported for duty. Getting to work this way everyday was not practical and was basically impossible. This raised various questions in both our minds - where have we ended up and have I done the right thing in accepting this job?' (ECHO 2010:n.p.)

The 'political disability' created within the country, did not impact her personal ability out of the country. Born in Africa, she moved to Europe, as this is where she was enabled to work.

\section{Struggle enablement at the United Nations}

Dr Varley had to spend the rest of her first day in this job and the following weeks talking to the personnel and United Nations security to find a solution to the problem. There was no obvious quick answer. The personnel did their very best to investigate a suitable solution:

'It seemed the only immediate and practical solution was that I be classified as cargo freight, so Allan and I got our ground passes encoded accordingly to enable use of the freight lifts. I could use the freight lifts by manoeuvring the huge exits doors which were very difficult to operate even for normal walking persons. With my body stability and being in a wheelchair, operation of the doors was a major effort.' (email, 12 June 2020)

On some occasions, the doors were not open and she had to request the help of the security.

\section{Disenabling: Getting to and from work was a major task}

The weather conditions also added to the difficulty and it involved increasing her distance tenfold. All the people that used this entrance were always helpful and went out of their way to help: 
'As an easier option we got permission to enter through Gate 2. Allan had to push me up the steep ramp every morning. In the evening I would leave through Gate 3, but this again was highly dependent on the weather.' (email, 12 June 2020)

Living in Vienna was clearly not easy:

'One day at Gate 2, a security guard mistakenly closed the gates too quickly, Allan and I had quite a shock as the boom gate come down on his head!' (email, 12 June 2020)

Dr Varley needed to enable herself to get through each day.

\section{Diplomatic car park}

In November 2006, the Varley's took possession of a car and were allowed to park in the diplomatic car park on the upper level. Despite other minor problems, this was a better way of getting to and from the office. In February 2007, she informed the Director General's office of the problems of getting to and from work:

'I suggested a practical economically viable possible option and easy solution of clearing the field between the U-Bahn and Wagramerstrasse and constructing a pathway which could be serviceable to all.' (ECHO 2010:n.p.)

She then learnt of a petition doing the rounds from mothers with kids in buggies:

' $[T]$ o improve access to the VIC from the U-Bahn by installing a lift on the side closest to the VIC or building a path. Feedback from the Director General and his office was very promising and positive.' (ECHO 2010:n.p.)

By the middle of the year 2007, a user-friendly and practical pathway was opened which provided access. This access was:

'[B]etween Gate 1, the U-Bahn, Wagramerstrasse and the apartment I was renting. For the very first time, the VIC, one of the headquarters of the United Nations, could be accessed by visitors in wheelchairs.' (ECHO 2010:n.p.)

Of Indian heritage, a quadriplegic South African Indian female enabled change in Vienna, Europe.

\section{Problems in the boardroom}

Just as soon as she 'had overcome one issue another was sure to raise its head. The next problem was the boardroom' (ECHO 2010). At a TRANSSC meeting in 2006, she was required to sit at the podium to assist the Unit Head and the coordinator. A special ramp had to be constructed to make it possible for her to access the podium in order to facilitate her duties to provide such assistance. With the new M-building as conference facilities being constructed, she was sure that, with two physically challenged staffmembers at the IAEA, the architects would have taken the opportunity to include wheelchair friendly facilities in their design:

'In 2009, my supervisor Jim Stewart and I paid an inspection visit. We were shocked to discover that even the new IAEA
Boardroom was also not suitable for physically challenged persons. I provided all the shortcomings to our director. She immediately brought this to the attention of the concerned persons, which led to discussions with conference services personnel.' (ECHO 2010:n.p.)

The meeting in July 2009 in the new M-building was a chance to see if things would work; but it was a disaster as agenda items had to be shuffled around before Dr Varley had some way of reaching the podium:

'My feedback on this palaver was once again provided. This is a United Nations building, and there are regulations and legislation on access for physically challenged persons. I consider that is not morally, ethically and professionally acceptable that the IAEA is not setting the standards by example. Daily we were interacting with people from throughout the globe. Different cultures and diverse physically challenged individuals needed to be accommodated for attendance at meetings.' (ECHO 2010:n.p.)

Once again, Dr Varley voiced her opinion and insisted that the disabled who have ability must be enabled as legislation is in place.

\section{Persons with disabilities}

Duty travel was another aspect that had to be tackled. In the latter part of the year 2009, Dr Varley was nominated to represent TSU together with her then supervisor at a Conference in Miami, USA:

'I then discovered that staff rules did not accommodate persons with any disabilities. The Agency made an exception in my case and I was informed that staff rules will be revised in the future. Unfortunately, my physical challenges are such that I cannot always manage by myself. Allan has been my God-sent angel and is always there to help me, whether it is going to the bathroom, the toilet, or picking me up when I misjudge the angle at which I get on or off the bed or simply fall off the bed when I am dressing or undressing.' (ECHO 2010:n.p.)

\section{Survival - A new enabling dimension}

For the Indian indentured labourers who left their motherland, being enabled to survive was uppermost in their consciousness. During the period of colonialism, being in a new country, with different traditions, values, customs, norms, working ethics, etc., survival took on a different dimension. Not only did they face having to work under inhumane working conditions, practice innovative ways of ritual worship and lead a different type of existence, but also they had to just cope with everyday difficulties meted to them by the colonialists through the sirdars on the plantations. For Rungasamy Pillay, to ensure the survival of his family, he had to remarry. Dr Varley, after having met with such a serious and life changing accident, allowed her survival mode to kick in and give new and renewed meaning to her life. 


\section{Ongoing challenges and hopes for the future}

Dr Varley follows a routine:

'My morning routine of getting to work in a respectable fashion is worth telling you about. On getting up I must first catheterise and then carry out the functions that mums do when cleaning a baby in getting them ready for the day!' (email, 12 June 2020)

This is a sad reality. From the time of awakening, it takes her at least one and a half to two hours to get ready for work:

'This is all dependent on the state I find myself awakening on. In summer I am exhausted just with the effort of getting dressed. I need padding due to a spastic bladder. I have special waterproof bedding, disposable linen savers and a pulsating air mattress bedcover to prevent bedsores. Of course, I must take all this stuff (except the air mattress) with me when I go on duty travel. I need sterilisation fluid for my catheter, which needs to be cleaned twice daily.' (email, 12 June 2020)

Prevention of urine infection is a major concern for physically challenged persons. Things that seem trivial to an ordinary person are huge challenges for the physically challenged. For example:

'I often have no symptoms when I get an illness, except for an increase in the frequency of the strong spasms that can throw me back off my chair - this has occurred a couple times. Due to my bad circulation, I get cold at night, so I use a hot water bottle. Time and again I burn myself without ever noticing. I only discover that I have burnt myself much, much later. It is only when infection threatens that I notice something is up.' (email, 12 June 2020)

Despite the various challenges facing every day, Dr Varley has pushed the boundaries of ability-disability and continues to strive to enable herself even though she acknowledges the need for assistance.

\section{Major adjustment to lifestyle}

Dr Varley loves to cook, but this can also be troublesome for her. Being paralysed from the chest down means that she has no control of any natural bodily functions. She has had to learn how to control the natural processes of bladder and bowel movements:

'I had to make many major adjustments to my lifestyle, both mentally and physically. I needed to accept and come to terms with being an adult but needing the care and attention of a child in many ways. This is the major mental and physical disability that I am faced with each day.' (email, 12 June 2020)

Abled people take walking and other activities for granted:

'Not being able to walk is not the major issue compared to my loss of independence concerning vital adult functions, which is most dehumanising. Being a free and determined person and needing to rely on help for simple functions that a six-year-old child is capable of is mentally and emotionally disturbing.' (email, 12 June 2020)
Evidently, Allan Varley, her husband since 2006 has stood by her:

'He looked after me as one would an infant - he washed, bathed, cleaned, dressed, cooked, fed and carried me as a mother or father would perform duties for a new-born baby. I cannot imagine my life without him.' (email, 12 June 2020)

\section{Next generation enabled}

One of her happiest days was the day:

'[M]y daughter, Rashika graduated from high school in 2005. I am forever grateful for the blessings that have been showered on me. Rashika, completed in 2009 a post-graduate degree in Copy Writing at a university in South Africa. In 2010 she came to us in Vienna. Thereafter, she travelled extensively for many years, getting jobs in Europe, the Far-East and Australia to support herself. Rashika is the head of a private English School in Trieste, Italy teaching English. I am happy to be alive, even though the things that I am faced with each day are frustrating to say the least.' (Interview, 12 January 2021)

Throughout her disability days, Dr Varley has ensured that her daughter has had the study opportunities that she once had. From one generation to the next, formal education is key to descendants of indentured Indians. Dr Varley has travelled all over the world.

\section{Wheelchair users}

During agency duty travel and before she joined the agency, she encountered many questionable instances:

'Generally, it seems the designers trying to accommodate physically challenged needs often had no clue of the real needs of wheelchair users. I had booked a wheelchair friendly room at the hotel, but my wheelchair could not fit in the door. We tried three separate hotels before we found one with a door that was wide enough!' (ECHO 2010:n.p.)

\section{Conclusion}

Colonialism, Indenture, South African Indian Community and Ability within Disability are the themes that were identified as key to this reflective memory article. For this article, the researchers established original information through the research process and this has been summarised and positioned thematically into this article. This article now initiates and institutes a platform from which further research may be originated as it has enhanced the knowledge on ability within disability which is applied specifically to the descendants of Indian indentured labourers in South Africa.

\section{Colonialism}

The British colonised India, South Africa and many other countries around the world. As people were transported over the oceans, they took with them aspects of their ancestral heritage, but also became acculturised to their new places of living. Rungasamy Pillay left colonial India in 1900 and landed in the Colony of Natal. He became a father to nine 
children in the Colony and a grandfather to many grandchildren. As he himself allowed personal achievements to take place during colonial life and times, so too, did his disabled granddaughter even though she grew up in the apartheid times. When she became a quadriplegic, she enabled herself albeit it during a different historical setting that being democracy. Because of health-related reasons, Dr Varley consequently resigned from her work at the VIC in 2016.

\section{Indenture}

The later generation displaced Indian community, having gone through the globalised political systems of colonisation and indenture, still faced further political disenfranchisement, pre- and post-1994. Indentured labour was abolished in 1911 after the Indian government legislated this into an Act. However, the descendants of the indentured labourers remained in Natal and the largest diaspora of Indians outside of India was found in Durban. Rungasamy Pillay would not have been able to predict that his eldest son's daughter would one day graduate with a doctorate at the age of 31 during the period of Apartheid.

\section{South African Indian community}

The term South African Indian refers to the South African citizens whose ancestry dates back to the period of colonisation and Indian indenture system. Reflective memory within social memory is important as reflective memories serve to remind the current generation via the reflective processes that the past informs the present. This is also true of the South African Indian community. Thus, it is postulated that reflective memories may select, maintain and manipulate information from working memory and long-term memory and promotes long-lasting memories (Craik \& Lockhart 1972; Roediger \& Karpicke 2006; Tulving 1962), which constitutes aspects of social memory.

Social memory then belongs to the community wherein individuals find themselves and thus it may be asserted that social memory then informs and enables that community. It is evident that achievements in life occurred in the Pillay family and the consequent descendants from that community. Whilst working at the IAEA, Dr Varley had to be classified as freight to mobilise herself at work because of her physical disability.

She moved from the borough of Verulam in South Africa to Vienna in Austria and eventually, because of her disabilities, retired and settled in a small village, Skirlaugh, in East Yorkshire in the United Kingdom. In 2017, the Varley's bought a house. Again, they were blessed as the house was owned by a quadriplegic and is well suited for her needs. The village has a population of approximately 1800 people, with one pub, a small shop and a post office. She is the only person of colour in this village and the people have accepted her with no hesitation, which she is thrilled about. Her peaceful life in this village is a far cry from colonisation, indenture, apartheid and post-South African democracy. Her story is chronicled with episodes which highlight her many abilities and achievements and demonstrate how she manages her disability whilst allowing her abilities to shine through.

\section{Ability within disability}

For the purposes of this article, the constructs of ability, personal physical disability and 'political disability' within the descendants of indentured labourers were considered. In order to research the aspect of ability and disability, unmediated reflections or the reflective memories of Dr Varley were documented and presented in this article as her memories serve or impact social memory by adding value to the understanding of long-lasting memories of communities. Dr Varley indicated that her work at the IAEA was very satisfying, both professionally and personally. Her abilities within the disability paradigm have been captured as it is a unique case of strength and inner power that helps to overcome the stresses of disabilities. The reflective memories shared via the telephonic interview, written for the ECHO Newsletter article or emailed responses to the questionnaire, highlight the numerous abilities that Dr Varley possessed. Her abilities enabled her to achieve success in life. Despite her disabilities later in life, she also enabled herself to achieve her objectives within the ability-disability paradigm. In her youth, Dr Varley was a victim of 'political disability' in South Africa as indicated by her words 'In spite of holding a doctorate degree in Chemistry I was unable to find employment with that qualification'.

\section{Acknowledgements Competing interests}

The authors declare that they have no financial or personal relationships that may have inappropriately influenced them in writing this article.

\section{Authors' contributions}

Both authors contributed equally towards this article.

\section{Ethical considerations}

The respondent was informed of the aims and objectives of this research. She graciously consented as it was clearly stated that the information received would be for research and academic purposes. The respondent was comfortable, and the brief interview took place telephonically even though a major part of the information was emailed after the respondent had answered questions from a research instrument. The respondent gave verbal consent and agreed to the contents of this article.

\section{Funding information}

This research received no specific grant from any funding agency in the public, commercial or not-for-profit sectors. 


\section{Data availability}

Data sharing is not applicable to this article, as no new data were created or analysed in this study.

\section{Disclaimer}

The views and opinions expressed in this article are those of the authors and do not necessarily reflect the official policy or position of any affiliated agency of the authors.

\section{References}

Bhana, S., 1991, Indentured Indian emigrants to Natal 1860-1902: A study based on ship lists, Promilla, New Delhi.

Britten, N., 1999, Qualitative interviews in healthcare, in C. Pope \& N. Mays (eds.), Qualitative research in health care, 2nd edn., pp. 11-19, BMJ Books, London.

Craik, F.I.M. \& Lockhart, R.S., 1972, 'Levels of processing: A framework for memory research', Journal of Verbal Learning and Verbal Behavior 11(6), 671-684. https:// doi.org/10.1016/S0022-5371(72)80001-X
Desai, A. \& Vahed, G., 2010, Inside Indian indenture: A South African story, 1860-1914, HSRC Press, Cape Town.

Gomm, R., Hammersley, M. \& Foster, P., 2000, Case study method, Sage, London.

IAEA Staff Newsletter, Vienna, ECHO spring 2010, viewed 12 August 2020, from https://www.iaea.org.

Johansson, R., 2007, 'On case study methodology', Open House International 32(3), 48-54. https://doi.org/10.1108/OHI-03-2007-B0006

Meer, F., 1969, Portrait of Indian South Africans, Avon House, Durban.

Mishra, V., 2008, The literature of the Indian diaspora: Theorizing the diasporic imaginary, Routledge, New York, NY.

Roediger, III. H.L. \&. Karpicke, J.D., 2006, 'Test-enhanced learning: Taking memory tests improves long-term retention', Psychological Science 17(3), 249-255. https://doi.org/10.1111/j.1467-9280.2006.01693.x

Stern, D.N., Sander, L.W., Nahum, J.P., Harrison, A.M., Lyons-Ruth, K., Morgan, A.C. et al., 1998, 'Non-interpretive mechanisms in psychoanalytic therapy: The 'something more' than interpretation: The process of change study group', International Journal of PsychoAnalysis 79, 903-921. viewed from https://icpla.edu/wp-content/uploads/2012/10/ Stern-D.N-Non-Interpreteive-Mechanisms-in-Psychoa.-Therapy-IntJ.-Psychoa.Stern-D.N.-Non-Interpreteive-Mechanisms-in-Psychoa.-Therapy-Int.J.-Psychoa.-
vol.79-1998.pdf.

Tinker, H., 1974, A new system of slavery: The export of Indian labour overseas, 1830-1920, Oxford University Press, New York, NY.

Tulving, E., 1962, 'Subjective organization in free recall of "unrelated" words', Psychological Review 69(4), 344-354. https://doi.org/10.1037/h0043150 